\title{
ASSESSMENT OF OPTIONS FOR THE COLLECTION, HANDLING, AND TRANSPORT OF CORN STOVER
}

Robert D. Perlack

Anthony F. Turhollow

OAK RIDGE NATIONAL LABORATORY 


\title{
DOCUMENT AVAILABILITY
}

Reports produced after January 1, 1996, are generally available free via the U.S. Department of Energy (DOE) Information Bridge.

Web site http://www.osti.gov/bridge

Reports produced before January 1, 1996, may be purchased by members of the public from the following source.

\author{
National Technical Information Service \\ 5285 Port Royal Road \\ Springfield, VA 22161 \\ Telephone 703-605-6000 (1-800-553-6847) \\ TDD 703-487-4639 \\ Fax 703-605-6900 \\ E-mail info@ntis.fedworld.gov \\ Web site http://www.ntis.gov/support/ordernowabout.htm
}

Reports are available to DOE employees, DOE contractors, Energy Technology Data Exchange (ETDE) representatives, and International Nuclear Information System (INIS) representatives from the following source.

Office of Scientific and Technical Information

P.O. Box 62

Oak Ridge, TN 37831

Telephone 865-576-8401

Fax 865-576-5728

E-mail reports@adonis.osti.gov

Web site http://www.osti.gov/contact.html

This report was prepared as an account of work sponsored by an agency of the United States Government. Neither the United States Government nor any agency thereof, nor any of their employees, makes any warranty, express or implied, or assumes any legal liability or responsibility for the accuracy, completeness, or usefulness of any information, apparatus, product, or process disclosed, or represents that its use would not infringe privately owned rights. Reference herein to any specific commercial product, process, or service by trade name,

trademark, manufacturer, or otherwise, does not necessarily constitute or imply its endorsement, recommendation, or favoring by the United States Government

or any agency thereof. The views and opinions of authors expressed herein do not necessarily state or reflect those of the United States Government or any agency thereof. 
Bioenergy Feedstock Development Program

Environmental Sciences Division

\title{
ASSESSMENT OF OPTIONS FOR THE COLLECTION, HANDLING, AND TRANSPORT OF CORN STOVER
}

\author{
Robert D. Perlack \\ Anthony F. Turhollow \\ Oak Ridge National Laboratory
}

Date Published: September 2002

\author{
Prepared for \\ U.S. Department of Energy \\ Office of Energy Efficiency and Renewable Energy \\ Biomass Program \\ Budget Activity Number EB 2404000
Prepared by
OAK RIDGE NATIONAL LABORATORY
P.O. Box 2008 \\ Oak Ridge, Tennessee 37831-6285 \\ managed by \\ UT-Battelle, LLC \\ for the \\ U.S. DEPARTMENT OF ENERGY \\ under contract DE-AC05-00OR22725
}




\section{CONTENTS}

\section{Page}

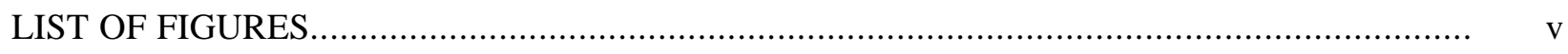

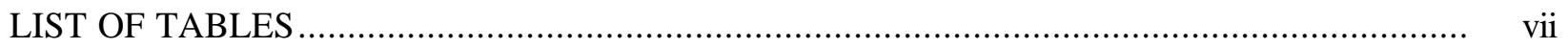

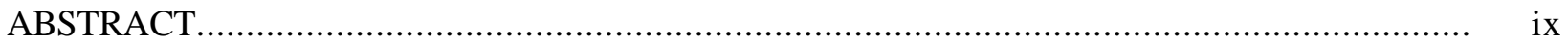

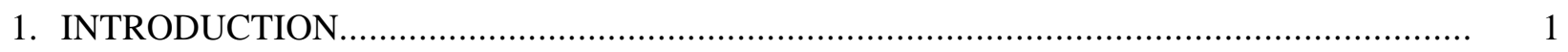

2. CORN STOVER AVAILABILITY ......................................................................

3. LOGISTICS OF HANDLING CORN STOVER ........................................................... 5

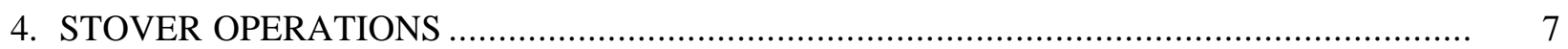

4.1 COLLECTING, BALING, AND HANDLING …............................................. 7

4.1.1 Large Round Bales........................................................................ 7

4.1.2 Large Rectangular Bales.................................................................... 8

4.1.3 Silage-collection System with Compacted Bales....................................... 8

4.1.4 Unprocessed-pickup System with Compacted Bales..................................... 8

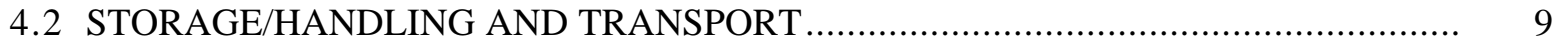

5. ASSESSMENT OF STOVER UTILIZATION OPTIONS .......................................... 11

5.1 LARGE ROUND AND LARGE RECTANGULAR BALES .................................... 11

5.2 SILAGE AND UNPROCESSED STOVER SYSTEMS........................................... 11

5.3 HAULING BALES FROM STORAGE............................................................ 14

5.4 FARMER PAYMENTS AND ADMINISTRATION COSTS .................................. 15

5.5 TOTAL DELIVERED COSTS OF BALED STOVER ........................................... 16

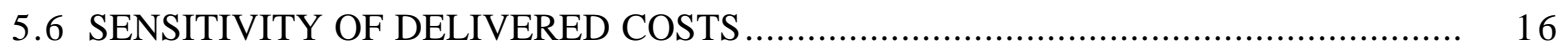

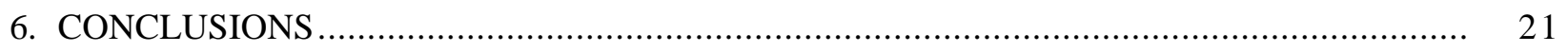

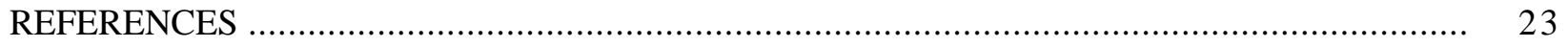

APPENDIX A. DETAILED EQUIPMENT COSTS .......................................................... 25 


\section{LIST OF FIGURES}

Figure $\quad$ Page

$1 \quad$ Effect of stover availability on average one-way haul distance ............................... 6

2 Cost of large round bales in storage ................................................................. 12

3 Cost of large rectangular bales in storage .......................................................... 12

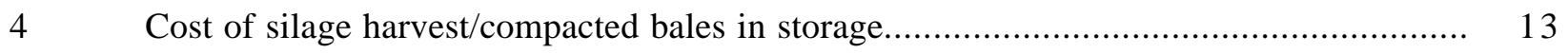

$5 \quad$ Cost of unprocessed pickup/compacted bales in storage ....................................... 13

6 Cost of unprocessed pickup/compacted bales in storage under alternative wagon

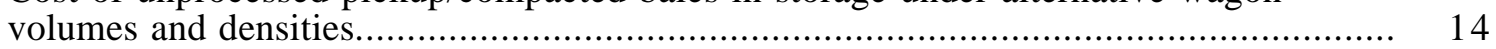

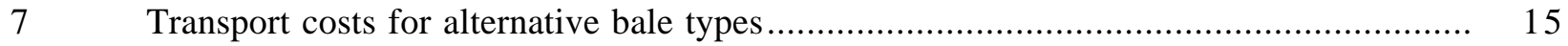

$8 \quad$ Cost summary for conventional bale systems................................................ 18

$9 \quad$ Cost summary for unprocessed pickup/compacted bale systems ............................ 18

10 Sensitivity of delivered costs to changes in stover availability - large round bales......... 19

11 Sensitivity of delivered costs to changes in stover availability - unprocessed pickup system. 


\section{LIST OF TABLES}

Table

Page

$1 \quad$ Corn stover yield and availability - base case assumptions.................................... 3

$2 \quad$ Estimated corn stover collection area and haul distance..................................... 5

$3 \quad$ Summary of delivered stover costs for large round, rectangular bales, and unprocessed/pickup system bales (high and low cost) ......................................... 17

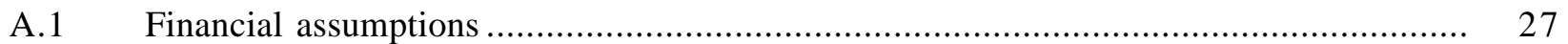

A.2 Equipment/implements assumptions and costs ................................................. 28 


\begin{abstract}
In this report, we discuss the logistics and estimate the delivered costs for collecting, handling, and hauling corn stover to an ethanol conversion facility. We compare costs for two conventional baling systems (large round bales and large rectangular bales), a silage-harvest system, and an unprocessedpickup system. Our results generally indicate that stover can be collected, stored, and hauled for about $\$ 43.60$ to $\$ 48.80 /$ dry ton $(\$ 48.10$ - $\$ 53.80 /$ dry $\mathrm{Mg}$ ) using conventional baling equipment for conversion facilities ranging in size from 500 to 2000 dry tons/day ( $450-1810$ dry Mg/day). These estimates are inclusive of all costs including farmer payments for the stover. Our results also suggest that costs might be significantly reduced with an unprocessed stover pickup system provided more efficient equipment is developed.
\end{abstract}




\section{INTRODUCTION}

Ethanol is being promoted as an alternative fuel because it can reduce dependence on foreign oil, improve regional and local air quality, and lower greenhouse gas emissions. The feedstock source for nearly all of the ethanol produced in the U.S. is corn grain. However, ethanol can also be made from the cellulosic and hemi-cellulosic components of most plants. Much of the growth in ethanol production is expected to come from the conversion of this material. One of the more significant sources of cellulosic plant material are agricultural residues and, in particular, corn stover. Corn stover consists of the stalk, cob, shuck, and leaves left behind following grain harvest. Collecting the stover can be easily accomplished by turning-off the spreader and/or chopper on the corn combine. Doing so creates a windrow of stover that can be picked-up by conventional hay baling equipment.

In this report, we evaluate the current economics of collecting, hauling, and storing corn stover. A financial cost model was developed and used to estimate delivered average costs for two conventional stover collection and handling systems (large round and large rectangular bales), a silage collection system, and a simple unprocessed-pickup system. For the large round and large rectangular bale systems, stover is baled in the field and then transferred to a storage area. For the silage and unprocessed systems, stover is collected in wagons and taken to a storage area where it is baled and stacked for storage. For each collection system, stover can be hauled to storage areas and from storage areas to a conversion facility with trucks and flatbed trailers or high-speed tractors and wagons. We also assess how stover availability, stover yield, and farmer participation affect delivered costs.

The analysis contained in this report is not location specific and constrained by the availability of resources, competing uses, or factor inputs. ${ }^{1}$ This study focuses on understanding the cost relationships between corn stover collecting, handling, storage, and hauling options and how these costs change as a function of scale in comparison with conversion costs. We analyze various collection and transport options for supplying stover to a centrally located ethanol facility ranging in size from 500 to 4000 dry tons/day (450 to 3630 dry $\mathrm{Mg} /$ day) of corn stover.

The next section of this report briefly discusses the corn stover resource and its availability. This is followed by discussion of the key logistical issues associated with the delivery of corn stover to a conversion facility. The fourth section outlines the specific options for each of the four collection stover systems -- large round, large rectangular, silage, and unprocessed collection. The fifth section contains the cost modeling results. The final section provides a summary of the major findings.

\footnotetext{
${ }^{1}$ An analysis by Walsh et al. (2001) addresses these site-specific issues, such as the competing uses and the location of multiple stover-demanding facilities.
} 


\section{CORN STOVER AVAILABILITY}

In the U.S., there are about 70 million acres (28 million ha) of corn harvested annually. This acreage yields nearly 10 billion bushels of corn and about 220 million dry tons (200 million dry $\mathrm{Mg}$ ) of corn stover. Generally, about one ton of corn stover is produced for each ton of grain harvested. A corn yield of $140 \mathrm{bu} / \mathrm{acre}(345 \mathrm{bu} / \mathrm{ha})$, the approximate yield of the largest corn growing states, generates about 3.3 dry tons/acre $(7.5$ dry $\mathrm{Mg} / \mathrm{ha}$ ) of corn stover. This estimate is derived from the product of corn yield, bushel weight, corn grain dry matter content, and stover/grain ratio (see Table 1).

The amount of corn stover that can be collected depends on a number of factors. These include the type and sequence of collection operations, the efficiency of the collection equipment, tillage and crop management practices, and environmental restrictions, such as the need to control erosion, maintain soil productivity, and maintain soil carbons levels. In our base case, we assume one-third of the corn stover left by the corn combine is collected. This is more conservative than the 40-50\% assumed by Schechinger and Hettenhaus (1999). Additional operations, such as shredding and raking, are needed to increase the collection fraction. For our base case, a corn harvest of $140 \mathrm{bu} / \mathrm{ac}$ (345 bu/ha) yields approximately 1.1 dry tons/ac (2.5 dry $\mathrm{Mg} / \mathrm{ha})$ of stover.

The total amount of stover available in an area not only depends on the stover yield and collection fraction but two other key factors -- the proportion of corn acreage surrounding the ethanol conversion facility and the number of farmers contracted to sell stover. Weather and seasonal conditions can also affect the amount of stover available. In our base case scenario, we assume $30 \%$ of the surrounding land area is planted in corn. We also assume that half of the farmers in an area contract to sell stover. This percentage could vary significantly depending on the prices they receive, the presence of competing uses for corn stover, and whether there are significant environmental factors that would make stover removal unacceptable to them. We assume that some stover (10\%) goes uncollected because of site accessibility and/or weather inhibiting factors. This means that the harvested fraction of land surrounding a facility is $13.5 \%$. Finally, we assume $10 \%$ of all stover collected is lost due to decomposition in storage and to handling.

Table 1. Corn stover yield and availability - base case assumptions

$\begin{array}{ll}\text { Stover yield assumptions } & 140 \mathrm{bu} / \mathrm{acre}(345 \mathrm{bu} / \mathrm{ha}) \\ \text { Corn yield } & 85 \% \mathrm{bs} / \mathrm{bu}(25.4 \mathrm{~kg} / \mathrm{bu}) \\ \text { Corn grain dry matter content } & 56 \mathrm{lbs} \\ \text { Bushel weight } & 1: 1 \mathrm{dry} \text { tons/acre }(7.5 \mathrm{dry} \mathrm{Mg} / \mathrm{ha}) \\ \text { Stover/grain ratio (dry matter basis) } & 3.3 \mathrm{dr} \\ \text { Stover yield } & 33 \% \\ \text { Stover collected } & 1.1 \mathrm{dry} \text { tons/acre }(2.5 \mathrm{dry} \mathrm{Mg} / \mathrm{ha}) \\ \text { Availability assumptions } & \\ \text { Density of corn acreage } & 30 \% \\ \text { Percentage of farmer's selling stover } & 50 \% \\ \text { Percentage of fields inaccessible/uncollected } & 10 \% \\ \text { Storage decomposition and handling losses } & 10 \%\end{array}$




\section{LOGISTICS OF HANDLING CORN STOVER}

Economies of scale are relatively significant for fuel ethanol conversion facilities. As plants increase in size, scale economies are offset somewhat by increased transport costs associated with hauling feedstocks greater distances. If we assume a circular collection area, average feedstock haul distance increases by about $41 \%$ with every doubling of conversion facility size. The increase in haul costs is not linear because as distance increases collection area increases exponentially. ${ }^{2}$

In addition to the demand or conversion facility size, average haul distance depends on the availability factors discussed previously - the surrounding area planted in corn, the number of farmers selling stover, the average stover yield, and the fraction of fields that might be inaccessible due to weather conditions. With our base case assumptions shown in Table 1, we calculate stover collection area for facilities ranging in size from 500 to 4000 dry tons/day (450 to 3630 dry $\mathrm{Mg} /$ day).* Collection area is calculated as:

$$
\text { Collection area }\left(\mathrm{mi}^{2}\right)=\frac{d}{f^{*} p^{*}(1-a) * y} * \frac{1}{640}
$$

where,

$\mathrm{d}=$ dry tons/year (300 operating days/year \& $10 \%$ losses in storage and handling)

$\mathrm{f}=$ density of corn acreage $(30 \%)$

$\mathrm{p}=$ percentage of farmer's selling stover $(50 \%)$

$\mathrm{a}=$ percentage of fields inaccessible $(10 \%)$

$\mathrm{y}=$ stover yield $(1.1$ dry tons/acre)

As summarized in Table 2, collection areas range from about $1500 \mathrm{mi}^{2}\left(3800 \mathrm{~km}^{2}\right)$ for a 500 dry ton/day (450 dry $\mathrm{Mg}$ /day) facility to $14,000 \mathrm{mi}^{2}\left(36,400 \mathrm{~km}^{2}\right)$ for a 4000 dry ton/day (3630 dry $\mathrm{Mg}$ /day) facility. For each collection area, the average one-way haul distance is also shown. This

Table 2. Estimated corn stover collection area and haul distance

\begin{tabular}{ccccc}
\hline $\begin{array}{c}\text { Facility size } \\
\text { (dry tons/day) }\end{array}$ & $\begin{array}{c}\text { Annual } \\
\text { feedstock } \\
\text { requirements } \\
\text { (dry tons/yr) }\end{array}$ & $\begin{array}{c}\text { Stover } \\
\text { collection } \\
\text { area }\left(\mathrm{mi}^{2}\right)\end{array}$ & $\begin{array}{c}\text { Average haul } \\
(\mathrm{mi})\end{array}$ & $\begin{array}{c}\text { Average haul } \\
\text { with winding } \\
\text { factor (mi) }\end{array}$ \\
\hline 500 & 166,670 & 1,740 & 16.6 & 21.7 \\
1000 & 333,330 & 3,470 & 23.5 & 30.7 \\
2000 & 666,670 & 6,950 & 33.3 & 43.4 \\
4000 & $1,333,330$ & 13,900 & 47.0 & 61.4 \\
\hline & & & & \\
(dry Mg/day) & $($ dry Mg/yr) & $\left(\mathrm{km}^{2}\right)$ & $(\mathrm{km})$ & $(\mathrm{km})$ \\
\hline & & & & \\
450 & 151,170 & 4,500 & 26.8 & 34.8 \\
910 & 302,340 & 99000 & 37.8 & 49.2 \\
1810 & 604,690 & 18,000 & 53.5 & 69.6 \\
3630 & $1,209,370$ & 36,000 & 75.7 & 98.4 \\
\hline
\end{tabular}

${ }^{2}$ Sperling (1984) discusses in much more detail sizing issues associated with biomass fuel plants.

*At a conversion rate of 80 gallons/dry ton, our chosen facility sizes would range from about 13 to 106 million gallon/year (50 to 400 million liters/year). The average production capacity for a dry-mill type ethanol plant is about 30 million gallons/year (110 million liters/year) and about 100 million gallons/year (380 million liters/year) for wet-mill type plants. 
distance is computed as the radius of the average collection area. To adjust straight-line distance to actual road distance, we assume a 30\% winding factor. From the smallest to largest conversion facility, the average one-way haul distance varies from about 22 miles $(35 \mathrm{~km})$ to 61 miles $(98 \mathrm{~km})$.

The availability of stover in an area and the amount removed or collected can greatly affect haul distance. In Figure 1, we show haul distance as a function of facility demand for low and high stover availability and the base case (Table 2). Stover availability is defined as the product of corn yield, corn acreage density, the collection fraction, farmer participation, and the fraction of fields assumed to go uncollected. We define low availability as having a corn yield of $100 \mathrm{bu} / \mathrm{ac}$, a corn acreage density of $15 \%$, a collection fraction of $25 \%$, a farmer participation rate of $40 \%$, and uncollected fields set at $20 \%$. Under high stover availability, we assume $160 \mathrm{bu} / \mathrm{ac}, 40 \%$ corn acreage density, $60 \%$ collection fraction, $80 \%$ farmer participation, and only $5 \%$ of fields uncollected. In general, the differences in availability factors result in a nearly five-fold increase in average haul distance for each plant size. The implications for delivered stover costs are discussed in Section 5.

A final consideration in evaluating the economics of stover collection is the need for storage. The stover harvest period usually runs between early-October to late-December. This limited collection season creates the need for dispersed storage areas, assuming the conversion facility will lack space to store nearly a years' supply of stover. The number of dispersed storage areas required determines an average haul distance from fields. For our base case scenario, we assume 50 dispersed storage sites with each site holding $2 \%$ of the total annual feedstock requirements. ${ }^{3}$ For 50 storage sites, the average field to storage area haul with a $30 \%$ road winding factor varies from about 3.1 to 8.7 oneway miles (4.9 to $13.9 \mathrm{~km}$ ) for 500 to 4000 dry ton/day (450 to 3630 dry $\mathrm{Mg} /$ day) facilities, respectively. Changes in the availability factor will have the same affect on field to storage area distance as storage area to conversion facility distance (Figure 1).

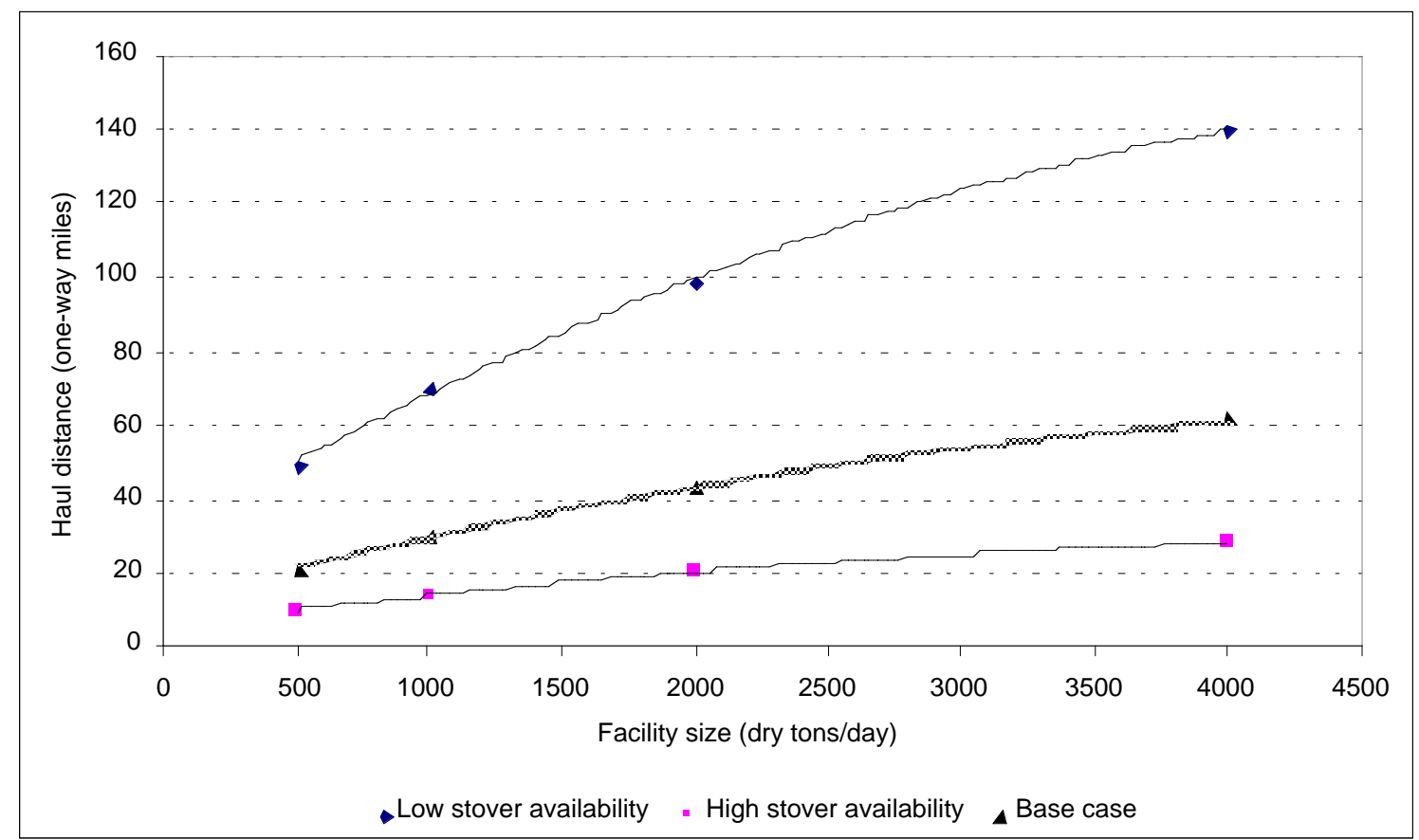

Fig. 1. Effect of stover availability on average one-way haul distance.

\footnotetext{
${ }^{3}$ This assumption is from a study by Sayler et al. (1993). They assume 50 storage areas (2\% maximum in each area) to lower fire risks.
} 


\section{STOVER OPERATIONS}

\subsection{COLLECTING, BALING, AND HANDLING}

Four options are evaluated for collecting corn stover -- large round bales, large rectangular bales, silage collection, and unprocessed-pickup. The large round and rectangular bale systems are typical of what is currently used to collect hay. The silage collection and unprocessed-pickup systems are untypical, but make use of available equipment that can be modified for corn stover collection and increased efficiency (i.e., high-capacity forage dump wagons and high-density stationary balers). For each system, there are alternative options for field staging, bale handling, and hauling. However, creation of the stover windrows is the same for all systems. Baling is done in the field for the large round and large rectangular bale systems. Baling is done at the storage areas for the silage collection and unprocessed-pickup systems. Loading bales at the storage areas and hauling to the conversion facility is the same for all systems. At the conversion facility, bales are unloaded and stacked.

\subsubsection{Large Round Bales}

Large round bales are approximately 6 feet $\times 5$ feet $(1.8 \times 1.5 \mathrm{~m})$ in size and weigh 1270 dry lbs $(580 \mathrm{~kg})$. The machine compliment for producing large round bales consists of a $120 \mathrm{hp}(90 \mathrm{~kW})$ tractor, megatooth pickup head, crop processor, and bale wagon. The addition of the crop processor increases the bale density. The productivity of the baler depends on a number of factors, such as operating width, speed, and field efficiency. We assume an operating width of 15 feet $(4.6 \mathrm{~m})$ and a forward travel speed of 5 miles/hour $(8 \mathrm{~km} / \mathrm{hr})$ at our base yield of 1.1 dry tons/acre $(2.5 \mathrm{dry} \mathrm{Mg} / \mathrm{ha})$. At greater stover yields, forward travel speed declines. The field efficiency of the baler is assumed to be $65 \%$. We further assume that it takes 1 minute to mesh-wrap each bale. The amount of stover produced each hour is about 5.2 dry tons (4.7 dry $\mathrm{Mg}$ ).

There are two options for moving bales from the field to storage areas. The first is to move the bales to the field edge with tractors and bale wagons, and then use trucks and flatbed trailers to transport from the field edge to storage. The second option is to move the bales directly from the field to storage with high-speed tractors (e.g., JCB 3185) and bale wagons. The high-speed tractors are capable of operating over the road.

Under the first option, we assume it takes 1 minute to load and unload each bale onto a bale wagon. The wagon has a capacity of 17 bales. We further assume an average field to field-edge distance of 0.5 miles $(0.8 \mathrm{~km})$ and an in-field travel speed of $10 \mathrm{miles} / \mathrm{hr}(16 \mathrm{~km} / \mathrm{hr})$. Total in-field time is 25 minutes at field efficiency $(80 \%)$. At the field edge, bales are loaded $(0.5$ minutes/bale $)$ onto flatbed trailers. The flatbed trailers have a capacity of 28 bales. Loading additional bales would exceed the legal road weight limit. Truck travel speed is 40 miles/hour $(65 \mathrm{~km} / \mathrm{hr})$. Unloading and stacking at the storage areas is assumed to take 0.5 minutes/bale.

For the second option, we assume the loaded bale wagons are moved to the field edge, a distance of 0.5 miles $(0.8 \mathrm{~km})$ and in-field travel speed of $10 \mathrm{miles} / \mathrm{hr}(16 \mathrm{~km} / \mathrm{hr})$. From the field edge to storage, travel speed is assumed to average $30 \mathrm{miles} / \mathrm{hr}(48 \mathrm{~km} / \mathrm{hr})$. Loading/unloading rates and equipment efficiencies are the same as the first option.

The key differences between these field to storage haul options are bale carrying capacity and loading/unloading operations. Trucks with flatbed trailers can carry more bales, but the bales must be loaded and unloaded with a telescopic loader. High-speed tractors pulling self-loading wagons eliminate the telescopic loader for loading and unloading steps the wagons. However, high-speed tractors are more expensive to operate and carry fewer bales. 


\subsubsection{Large Rectangular Bales}

The large rectangular bale system is configured with a $160 \mathrm{hp}(120 \mathrm{~kW})$ tractor, rectangular baler (e.g., Case 8590), and bale wagon. The bales are approximately $9 \times 4 \mathrm{ft}(2.7 \times 1.2 \mathrm{~m})$ square with a density of $9 \mathrm{lbs} / \mathrm{ft}^{3}\left(144 \mathrm{~kg} / \mathrm{m}^{3}\right)$ or nearly $1300 \mathrm{lbs} / \mathrm{bale}(588 \mathrm{~kg} / \mathrm{bale})$. The operating width of the baler is $15 \mathrm{ft}(4.6 \mathrm{~m})$ with a forward speed of $5.1 \mathrm{miles} / \mathrm{hr}(8.2 \mathrm{~km} / \mathrm{hr})$ and field efficiency of $80 \%$. The area covered by the baler is about $7.3 \mathrm{acres} / \mathrm{hr}(2.9 \mathrm{ha} / \mathrm{hr})$. Higher stover yields reduce the forward speed. Bale pickup time is a function of the field efficiency, area covered, and yield or about 2.8 to 2.0 minutes/bale. Bale wrap time is 1 minute. At the base yield of 1.1 dry tons/acre ( 2.5 dry $\mathrm{Mg} / \mathrm{ha}$ ), about 6.4 dry tons (5.8 dry $\mathrm{Mg}$ ) can be baled each hour.

The in-field capacity of the wagon is 10 bales. As with round bales, bales can be staged at the field edge and moved to storage on trucks and flatbed trailers or they can be moved directly from the field to storage with high-speed tractors (e.g., JCB 3185) and bale wagons. Specific assumptions are identical to the large round bale system except the bale wagon is limited to a load of 10 bales (infield and road) and the flatbed trailers to 26 bales.

\subsubsection{Silage-collection System with Compacted Bales}

Silage-collection systems are used to harvest corn silage and some hay silage. This equipment chops the stover into short billets that can be thrown into wagons. Compared to corn silage, the dry matter yield of corn stover is relatively low. We configure this option with a tractor-pulled forage harvester with an attached high-dump forage wagon. Forage harvesters have relatively slow forward speeds. The ASAE lists the average speed of a tractor-pulled forage harvester at $3 \mathrm{miles} / \mathrm{hr}(4.8 \mathrm{~km} / \mathrm{hr})$. Because of the relatively low yield, we assume that the speed of the tractor-pulled forage harvester is about $4 \mathrm{miles} / \mathrm{hr}(6.4 \mathrm{~km} / \mathrm{hr})$. We estimate a production rate of about 5.4 dry tons $/ \mathrm{hr}(4.9 \mathrm{dry} \mathrm{Mg} / \mathrm{hr})$ assuming equipment field efficiency is $70 \%$.

We also evaluate two options for moving the stover from the field to the storage areas where it is baled, stacked, and stored. First, forage wagons can be pulled to the field edge. Loaded forage wagons are then dumped into silage trailers and hauled to the storage areas. The second option is to pull the loaded forage wagons directly to the storage area from the field using the high-speed tractors.

A limitation with the silage system is that corn stover is not dense $\left(\sim 4 \mathrm{dry} \mathrm{lb} / \mathrm{ft}^{3}, 64 \mathrm{dry} \mathrm{kg} / \mathrm{m}^{3}\right)$ and this reduces the economic transport distance. At this density and using one of the largest high-dump forage wagons available $\left(1100 \mathrm{ft}^{3}, 31.2 \mathrm{~m}^{3}\right)$, the load is only 2.2 dry tons $(2.4$ dry $\mathrm{Mg})$. This load is far less than the 12-ton $(10.0 \mathrm{Mg})$ weight load of the wagon. In order to take advantage of the weight load, we hypothesize the availability of wagons that compress corn stover to $7.3 \mathrm{dry} \mathrm{lbs} / \mathrm{ft}^{3}$ $\left(118 \mathrm{dry} \mathrm{kg} / \mathrm{m}^{3}\right)$ with volumes of 1100 to $2200 \mathrm{ft}^{3}\left(31.2\right.$ to $\left.62.3 \mathrm{~m}^{3}\right)$. These compressing wagons have upper portions of the two sides perpendicular to the axles that are open as the wagons fill. These sides close together to compress the corn stover. The loads that can be carried range from about 4.0 to 8.0 dry tons ( 4.4 to 8.8 dry $\mathrm{Mg}$ ) for compressing wagons ranging in size from 1100 to $2200 \mathrm{ft}^{3}$ (31.2 to $\left.62.3 \mathrm{~m}^{3}\right)$.

At the storage area, high-density large rectangular bales are made using a stationary baler. Bales are then stacked and stored.

\subsubsection{Unprocessed-pickup System with Compacted Bales}

One means to reduce the cost of delivered corn stover is to minimize equipment and handling operations. Although a silage system has a minimal number of operations, it uses a relatively expensive forage harvester. What is proposed under this system is using a tractor of medium size (80 $\mathrm{hp}, 60 \mathrm{~kW}$ ) with a pickup unit attached to the front that gathers up the stover and shoots it into a forage wagon. In this unprocessed-pickup system, the corn stover is not reduced in size. 
This unprocessed-pickup system thus has a lower packing density than the silage system $(\sim 3$ dry $\mathrm{lbs} / \mathrm{ft}^{3}$ or $\left.48 \mathrm{dry} \mathrm{kg} / \mathrm{m}^{3}\right)$. This translates into a load of only 1.6 dry tons $(1.8$ dry $\mathrm{Mg})$. The silage system has a somewhat higher density because the stover is chopped into smaller pieces that pack more densely. To overcome the low density, we again assume the availability of higher volume wagons with a compression capability to $5.5 \mathrm{dry} \mathrm{lbs} / \mathrm{ft}^{3}\left(88 \mathrm{dry} \mathrm{kg} / \mathrm{m}^{3}\right)$. We consider the same two options for moving stover from the field to storage areas.

At the storage area, high-density large rectangular bales are made using a stationary baler. The compacted bales are then stacked and stored.

\subsection{STORAGE/HANDLING AND TRANSPORT}

Long-term storage of stover is required given the limited length of the collection season. We assume that there is no field storage and all collected stover is contained at storage areas with the exception of a small working supply ( $\sim 3$ days) at the conversion facility. At each storage area, incoming bales are handled and stacked. For the silage-collection and unprocessed-pickup systems, incoming loads are dumped, gathered, and loaded in a stationary baler or compactor. The compacted bales are then stacked.

The size of the storage areas will depend on the annual feedstock requirements, the size and density of the stover bales, the bale stacking configuration, and the space needed for handling bales. We assume round bales are stacked in a 300-bale pyramid configuration (12 bales wide, 6 bales deep, and 5 bales high). The large rectangular and compacted bales are stacked in 360-bale cubes (9 bales wide, 10 bales deep, and 5 bales high). Additional space required for handling equipment and access is assumed to be equal to that of the bale area. The land requirements for each intermediate storage area vary according to the size of the conversion facility and the type of bale. For example, a 2000 dry ton/day (1810 dry $\mathrm{Mg} /$ day) facility would need 50 storage areas of 8 acres for round bales and about 3 acres for compacted bales.

We assume trucks and flatbed trailers are used to move bales from storage to a conversion facility. Although high-speed tractors and bale wagons could be used, they are more costly given the distances involved. The haul distance depends on facility demand and the factors affecting stover yield and availability. We assume it takes about 1 minute to load and unload each bale, about 20 minutes to prepare the trailer including strapping the load. The size of the load is limited 25 tons $(22.6 \mathrm{Mg}$ ) or about 30 large round bales, 26 large rectangular bales, and 13 compacted bales. We also assume a travel speed of $45 \mathrm{miles} / \mathrm{hr}(73 \mathrm{~km} / \mathrm{hr})$. 


\section{ASSESSMENT OF STOVER UTILIZATION OPTIONS}

\subsection{LARGE ROUND AND LARGE RECTANGULAR BALES}

The costs of producing large round and large rectangular bales for facility sizes ranging from 500 to 4000 dry tons/day (450 to 3630 dry Mg/day) are summarized in Figs. 2 and 3. Costs include baling, moving bales to the storage sites, stacking bales, and storage. Also shown are the two options for moving bales to storage - staging bales at the field edge and moving them to storage with trucks and flatbed trailers or moving the bales directly from the field to storage with high-speed tractors and bale wagons.

For the large round bales, costs are about $\$ 22.30 /$ dry ton $(24.60 /$ dry $\mathrm{Mg}$ ) for a 500 dry ton/day (450 dry $\mathrm{Mg} /$ day) facility and increase to about $\$ 25 /$ dry ton $(\$ 27.60 /$ dry $\mathrm{Mg}$ ) for a 4000 dry ton/day (3630 dry Mg/day) facility. Hauling round bales directly from the field is less expensive than staging the bales at the field edge and hauling with truck and flatbed trailers for facility sizes up to about 3000 dry tons/day (2720 dry $\mathrm{Mg} /$ day). Our results generally indicate that large rectangular bales are about $\$ 1.40 /$ dry ton $(\$ 1.50 /$ dry $\mathrm{Mg}$ ) to $\$ 3.30 /$ dry ton $(\$ 3.60 /$ dry $\mathrm{Mg})$ more expensive for the range of facility sizes shown. In contrast to the large round bales, hauling large rectangular bales with trucks and flatbed trailers is less expensive than the direct haul with tractors and bale wagons for all but the smallest facility sizes.

\subsection{SILAGE AND UNPROCESSED STOVER SYSTEMS}

The silage collection system utilizes a tractor, a forage harvester with a windrow pickup head, and hidump forage wagons. The second system, unprocessed pickup, utilizes a tractor, a windrow pickup head, and forage wagons. Unlike the silage collection system, there is no chopping or processing of the corn stover in the field. Because this system uses less expensive equipment, costs are about $\$ 5$ $7 /$ dry ton $(\$ 5.50-\$ 7.70 /$ dry $\mathrm{Mg}$ ) lower than the silage pickup system. Costs for both systems are summarized in Figs. 4 and 5.

We see from Figs. 4 and 5 that hauling the stover with high-speed tractors directly from the field is less costly than transferring the stover to trucks at the field edge for facilities under about 1500 dry tons/day (1360 dry Mg/day) for the silage system and slightly less for the unprocessed-pickup system. At larger facility sizes, truck haul to the storage areas is less expensive. In comparing between these two systems, there is a cost difference of $\$ 5.10 /$ dry ton $(\$ 5.60 / \mathrm{dry} \mathrm{Mg}$ ) at the smallest sized facility when hauling directly from the field and about $\$ 6.30 /$ dry ton $(\$ 6.90 / \mathrm{dry} \mathrm{Mg}$ ) at the largest sized facility using truck haul. Overall, the unprocessed pickup system is less costly than the silage collection system. The extra density achieved by chopping the stover (greater wagon loads) does not offset the higher capital cost of the forage harvester.

To assess the effect of stover density on the costs of the unprocessed pickup system we vary the volume and density of the wagon loads. This is shown in Fig. 6 along with the least cost results from Fig. 5, denoted as "loose" in Fig. 6. One case assumes the same wagon volume $\left(1100 \mathrm{ft}^{3}, 31.2 \mathrm{~m}^{3}\right)$ but the stover is compressed to achieve a near doubling of the packing density. The wagon load in this case increases by about $80 \%$. The second case doubles the size of the wagon volume to $2200 \mathrm{ft}^{3}$ $\left(62 \mathrm{~m}^{3}\right)$ and increases the packing density. The wagon load increases to 6 dry ton $(5.5 \mathrm{dry} \mathrm{Mg})$. Adding the compressing capability to the wagon has the effect of lowering costs in storage by about $\$ 4.00$ dry ton $(\$ 4.40 /$ dry $\mathrm{Mg}$ ) for the smallest facility and by about $\$ 5.10 /$ dry ton $(\$ 5.60 / \mathrm{dry} \mathrm{Mg}$ ) for the largest sized facility. Doubling the size of the wagon can further reduce costs, but this change is smaller relative to the cost reduction achieved by increasing packing density. 


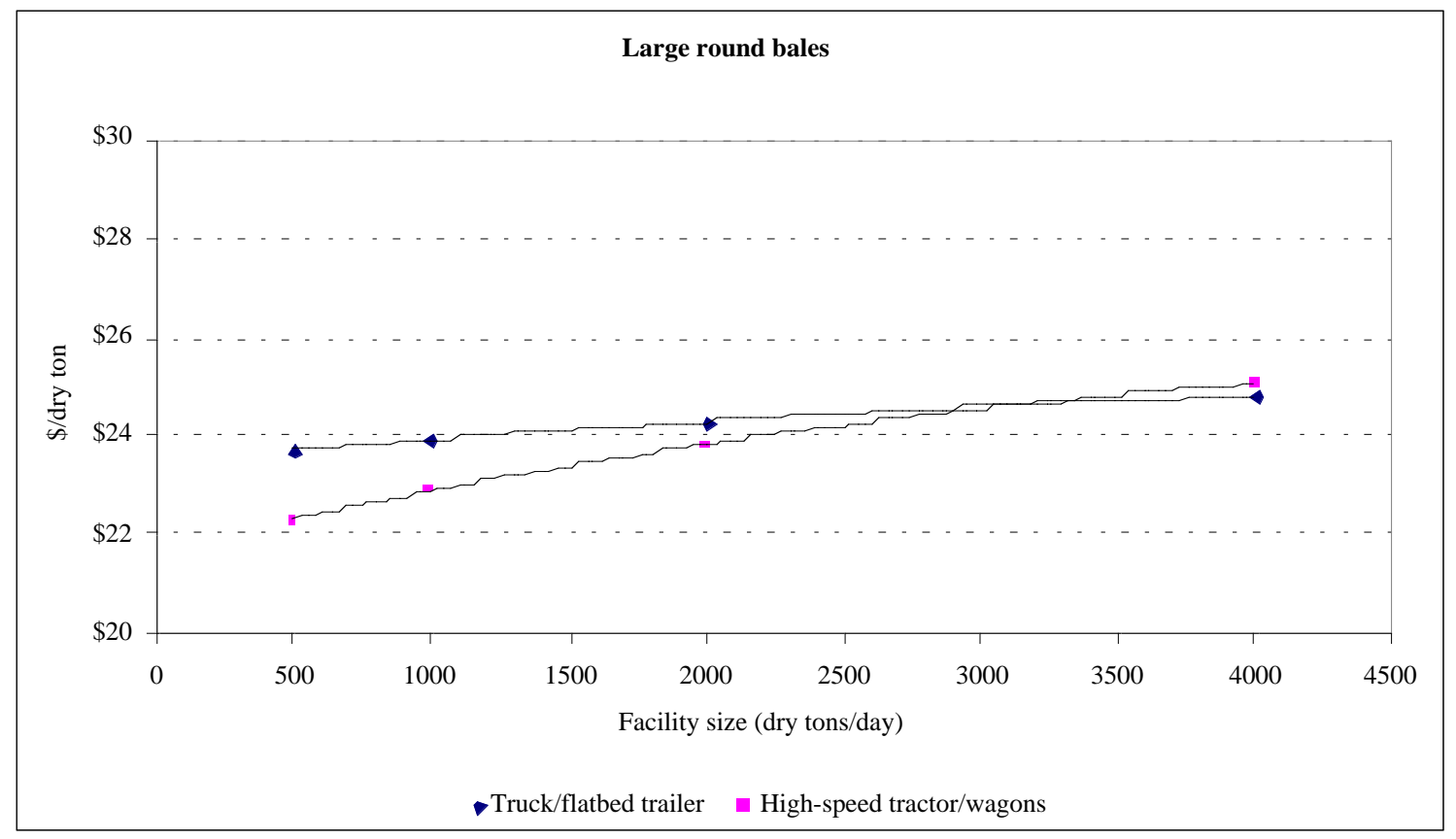

Fig. 2. Cost of large round bales in storage.

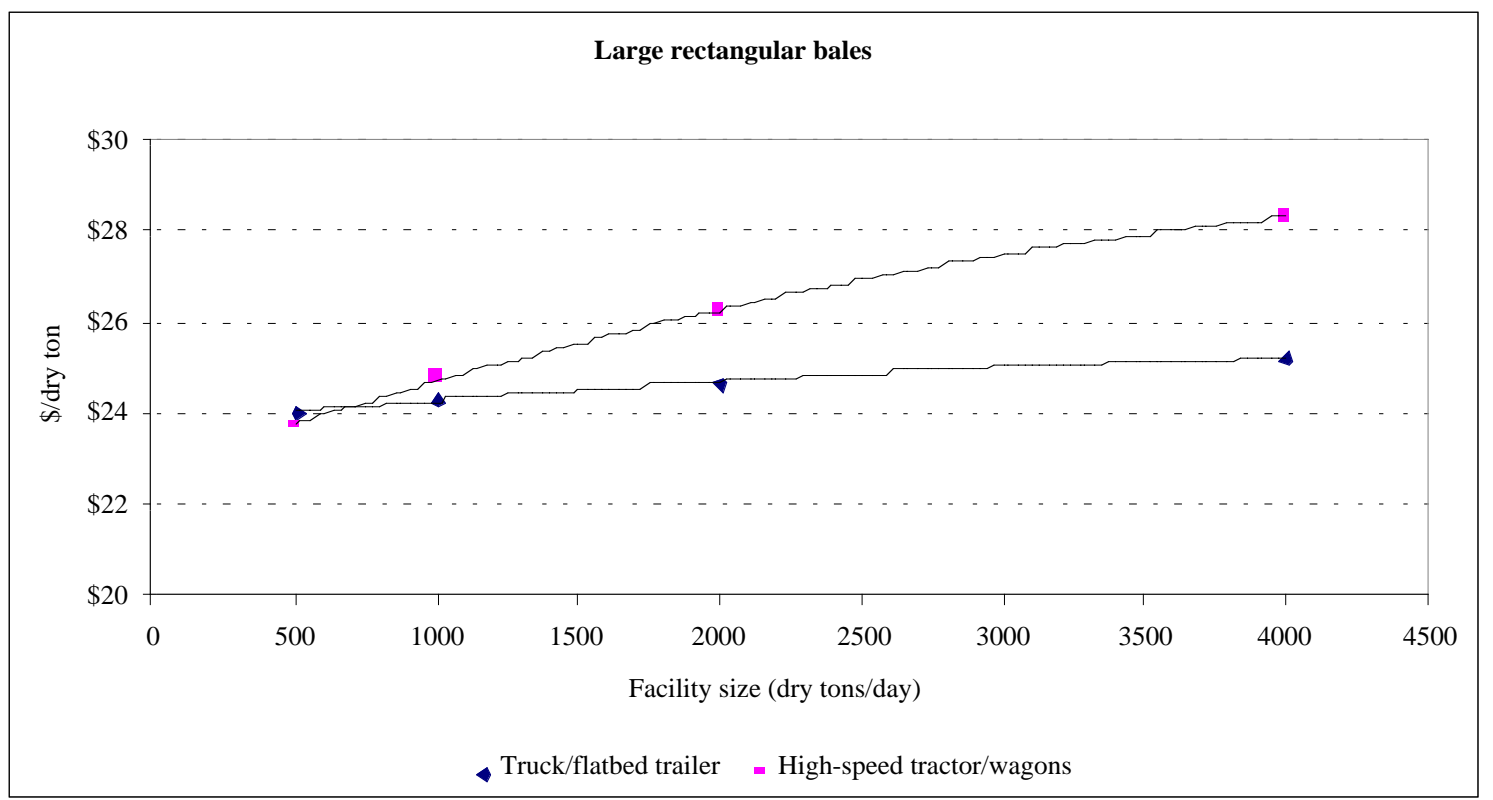

Fig. 3. Cost of large rectangular bales in storage. 


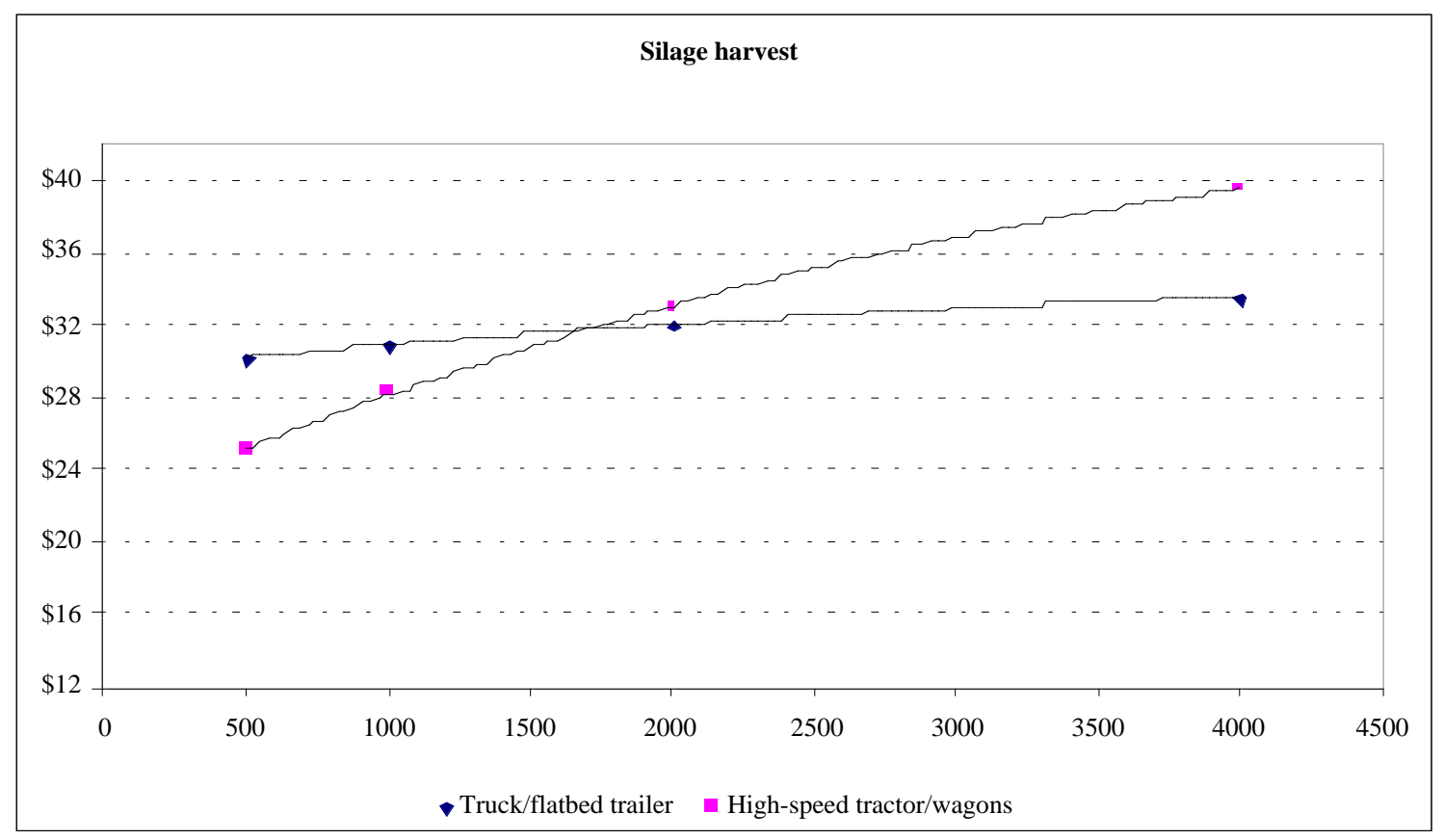

Fig. 4. Cost of silage harvest/compacted bales in storage.

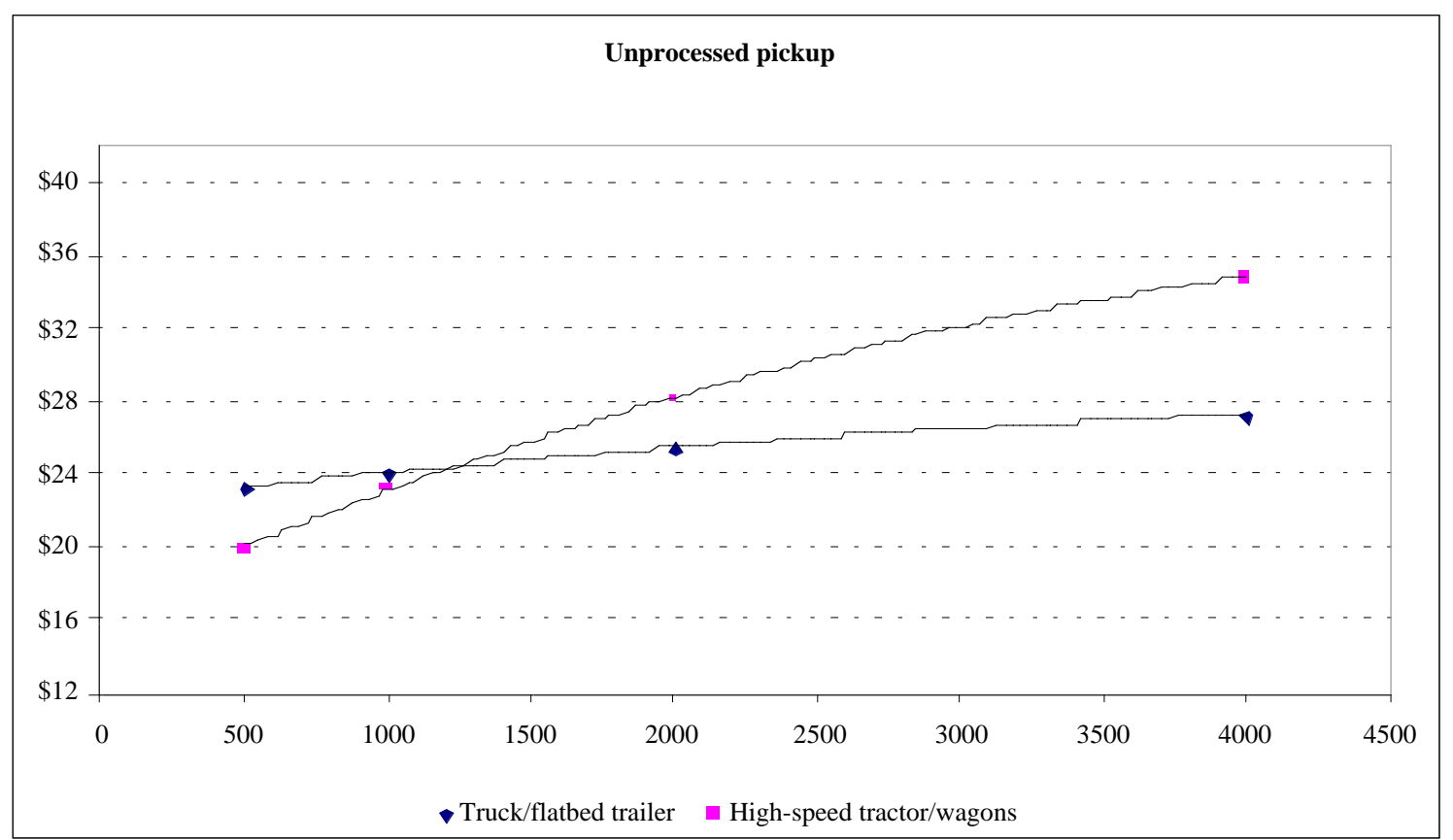

Fig. 5. Cost of unprocessed pickup/compacted bales in storage. 


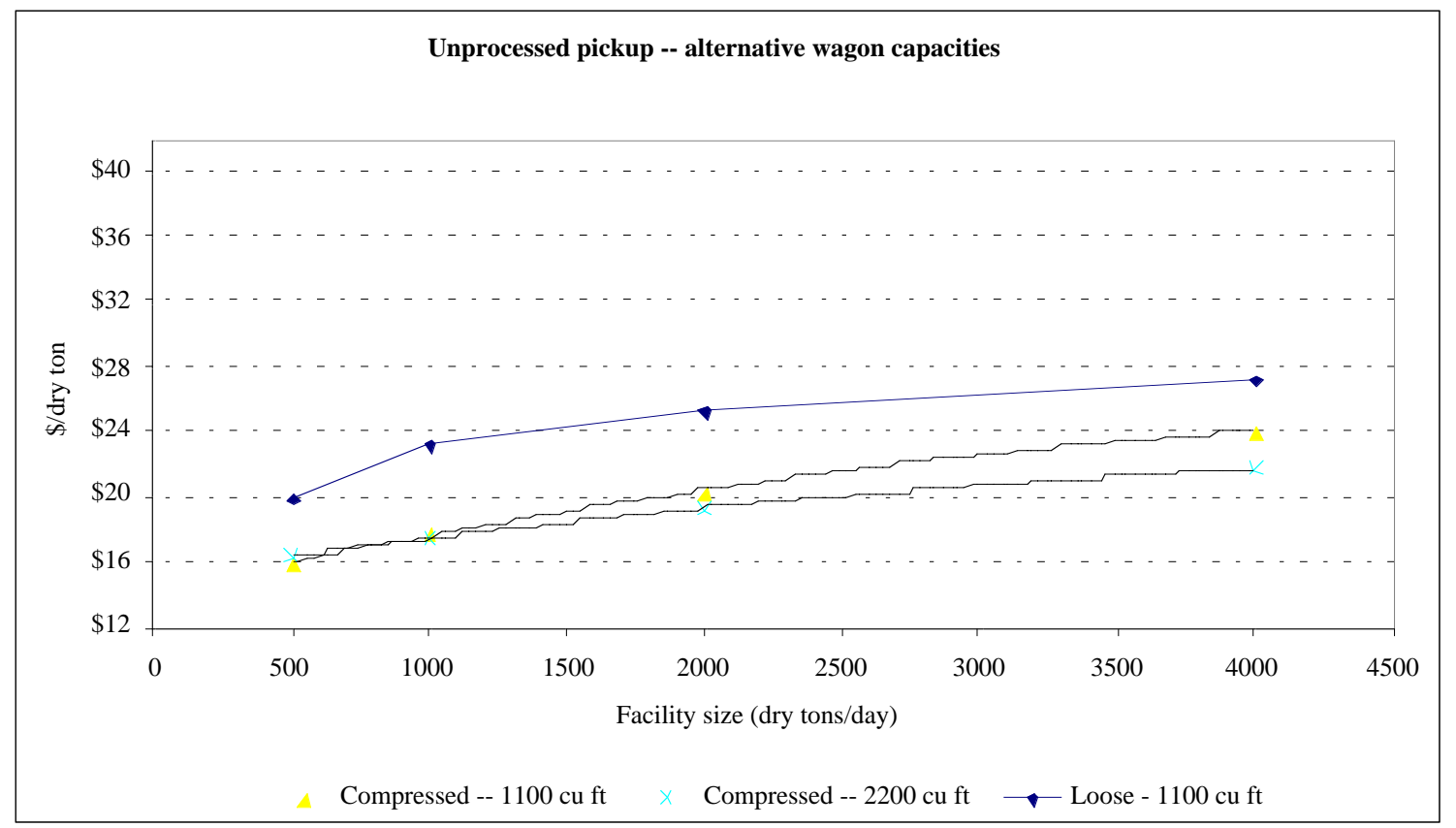

Fig. 6. Cost of unprocessed pickup/compacted bales in storage under alternative wagon volumes and densities.

\subsection{HAULING BALES FROM STORAGE}

The costs of transporting bales from storage to a conversion facility are estimated for trucks pulling one flatbed trailer. A single 53 foot $(16 \mathrm{~m})$ long trailer can haul the legal 50,000 lb load limit $(22,670 \mathrm{~kg})$ of round mesh-wrapped bales, large rectangular, and compacted bales, assuming a $25 \%$ moisture content. High-speed tractors pulling bale wagons are not cost competitive with trucks beyond a haul distance of a few miles. This is because of higher operating costs, slower travel speeds, and lower haul weights.

The transport cost functions for moving the three bale types from storage to a conversion facility are depicted in Figure 7. The estimated transport cost functions show that bale density matters. The least dense bales are the most expensive to move and the compacted bales the least expensive. The largeround mesh-wrapped and large rectangular bales are nearly identical in cost. Generally, transport costs range between $\$ 7.00$ and $\$ 10.50 /$ dry ton $(\$ 7.70$ and $\$ 11.60 /$ dry $\mathrm{Mg}$ ) for conventional bales and between $\$ 4.20$ and $\$ 7.30 /$ dry ton $(\$ 4.60$ and $\$ 8.10 /$ dry $\mathrm{Mg}$ ) for the compacted bales depending on facility size. 


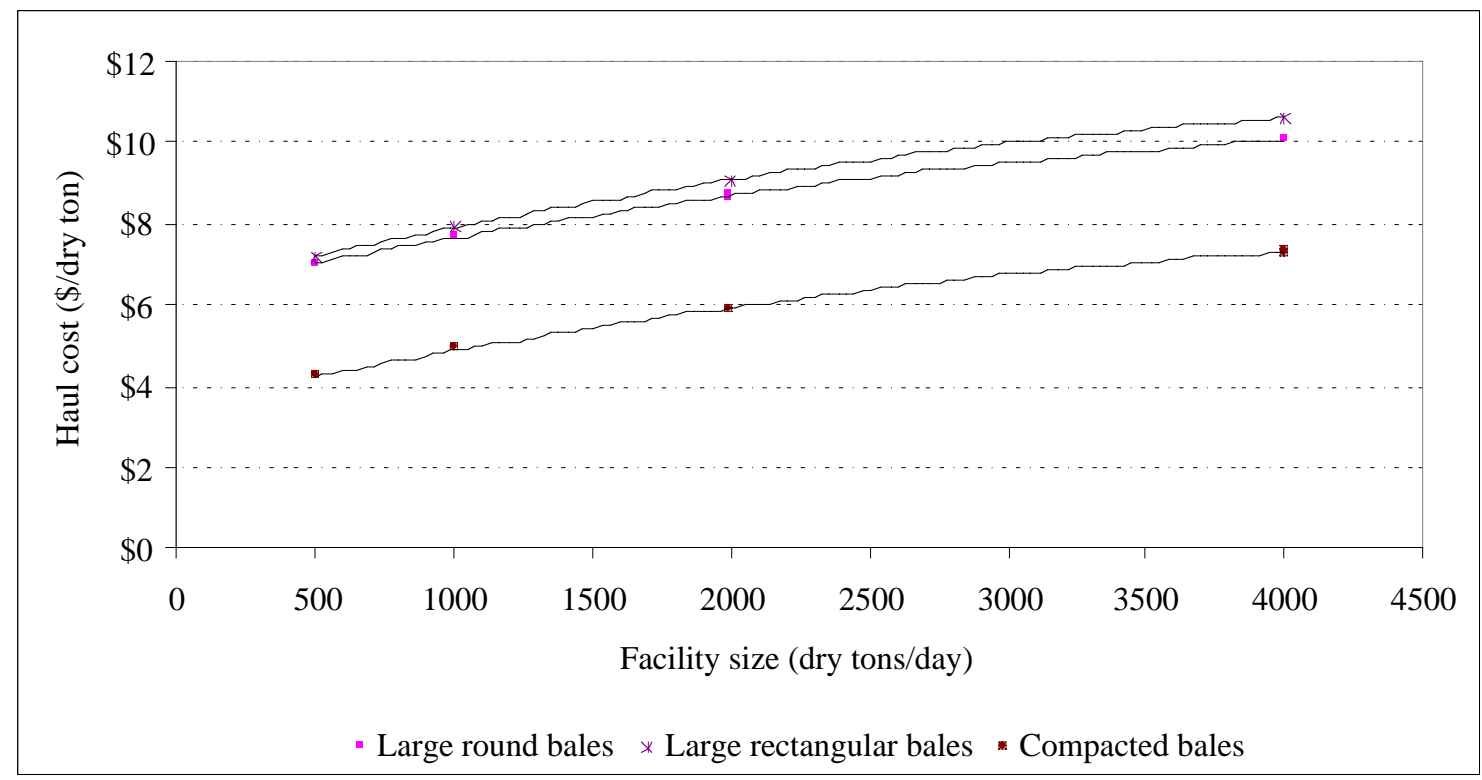

Fig. 7. Transport costs for alternative bale types.

\subsection{FARMER PAYMENTS AND ADMINISTRATION COSTS}

The amount paid to corn growers to create the stover windrows is dependent on a number of factors. At a minimum, the amount paid to growers for the stover should cover the value of the removed nutrients. Nielsen estimated the nutrient value of corn stover at $\$ 5.90 /$ dry ton $(\$ 6.50 /$ dry $\mathrm{Mg})$. Jose and Brown report a nutrient value of $\$ 9.60 /$ ton $(\$ 10.60 / \mathrm{Mg})$ and Sayler et al. report $\$ 7.00$ to $\$ 8.00 /$ ton $(\$ 7.70$ to $\$ 8.80 / \mathrm{Mg})$. Schechinger and Hettenhaus (1999) calculate a nutrient value of $\$ 10.40 /$ acre (\$25.70/ha) assuming 1.5 dry tons/acre (3.4 dry $\mathrm{Mg} / \mathrm{ha}$ ) of stover removed. However, their specific grower compensation policy is based on transport distance with payments to growers ranging from $\$ 15 /$ dry ton $(\$ 16.50 /$ dry $\mathrm{Mg}$ ) for haul distances within 15 miles $(24 \mathrm{~km})$ and $\$ 7.00 /$ dry ton $(\$ 7.70 / \mathrm{dry} \mathrm{Mg}$ ) for haul distances 51 to 100 miles $(82$ to $161 \mathrm{~km})$. Hettenhaus et al. (2000) report farmers may offer stover at $\$ 10.00 /$ acre $(\$ 25.00 /$ ha) or less if nutrient availability is not a major concern. However, where potassium and phosphorus are needed, farmers may want more than $\$ 20 /$ acre ( $\$ 50 / \mathrm{ha}$ ) for the stover. The price paid to growers could also include compensation for potential soil compaction and decreased surface organic matter.

In addition to the direct compensation for the loss of the stover value, a profit to the corn grower can be expected. Given the many unknowns surrounding arrangements for the purchase of corn stover, we assume total farmer compensation of $\$ 10 /$ dry ton $(\$ 11 /$ dry $\mathrm{Mg}$ ) to cover nutrients removed and a profit. We expect that this amount could be slightly lower but could also be much more if there are competing uses within an area and markets for higher-value bio-based products develop.

There is also likely to be considerable administrative requirements associated with the procurement of corn stover. These administrative costs will include planning the collection operations, selecting operators, and coordinating the actual sequencing of operations. In order to account for these costs, we assume a $5 \%$ administrative operations expense levied on collection, hauling, storage, and farmer payments. 


\subsection{TOTAL DELIVERED COSTS OF BALED STOVER}

This section combines the costs of stover collection, handling, hauling to storage areas, storage, and transport costs to a conversion facility. It also includes the price paid to corn growers for the stover and the operations expense to cover coordination and management of the stover collection activities. The sum of these costs is the average cost of baled stover delivered and stacked at the conversion facility. The costs for breaking the bales (e.g., tub grinding) and any subsequent feedstock processing are assumed in the conversion facility costs. Including bale breaking in the feedstock cost adds another $\$ 4.70 /$ dry ton $(\$ 5.20 /$ dry $\mathrm{Mg})$.

Table 3 and Figs. 8 and 9 displays average delivered costs for baled corn stover as a function of facility size. For large round bales and large rectangular bales, delivered costs range from about $\$ 42.70 /$ dry ton $(\$ 47.10 /$ dry $\mathrm{Mg}$ ) for the smallest sized facility to $\$ 47.10 /$ dry ton $(\$ 51.90 / \mathrm{dry} \mathrm{Mg})$ for the largest sized facility. The difference in costs between facility size reflects increased transport distance. The large rectangular bales are about $\$ 0.60$ to $\$ 1.10 /$ dry ton $(\$ 0.70$ to $\$ 1.20 / \mathrm{dry} \mathrm{Mg}$ ) more expensive than the large round bales as facility size increase from 500 to 4000 dry ton/day (450 to 3630 dry $\mathrm{Mg} /$ day). Both of these systems are configured with commercially available equipment, although large rectangular balers are not as common as round balers.

The unprocessed pickup system, configured high-dump wagons forage wagons and a high-density stationary baler, may be less expensive than either of the conventional bale systems especially at the smaller facility sizes (Fig. 9). However, the equipment for collecting, hauling, and compacting stover is not proven. Doubling the capacity of the forage wagons and increasing the packing density by assuming wagon compressing capability may give an indication of the potential for cost reduction. We estimate this cost reduction at about $\$ 11.10 /$ dry ton $(\$ 12.20 /$ dry $\mathrm{Mg})$ for the smallest facility to about $\$ 6.20 /$ dry ton $(\$ 6.80 /$ dry $\mathrm{Mg}$ ) for the largest sized facility.

\subsection{SENSITIVITY OF DELIVERED COSTS}

A critical determinant to low stover delivered costs is availability. As discussed earlier, stover availability is determined by the corn yield and the fraction of stover removed as well as other landscape factors - the density of corn acreage, the percentage of farmers contracted to sell stover, and weather-related factors, such as the fraction of fields that go uncollected. In Figs. 10 and 11, we show how stover availability affects delivered costs for large round bale system and the unprocessed pickup system, respectively. We define a low availability and high availability case and also show our base case costs for each system. Low availability is defined as a corn yield of $100 \mathrm{bu} / \mathrm{acre}$ (250 $\mathrm{bu} / \mathrm{ha}$ ), a stover collection fraction of $25 \%$, a corn acreage density of $15 \%$, a $40 \%$ farmer participation rate, and an uncollected field fraction of $20 \%$. Our high stover availability case is based on a yield of $160 \mathrm{bu} / \mathrm{acre}(400 \mathrm{bu} / \mathrm{ha})$, a $60 \%$ collection fraction, a $40 \%$ corn land density, an $80 \%$ farmer participation rate, and an uncollected field fraction of $5 \%$.

Our results show that high stover availability would have the effect of lowering delivered costs of large round bales from about $\$ 5.80$ to $\$ 8.20$ /dry ton ( $\$ 6.40$ to $\$ 9.00 / \mathrm{dry} \mathrm{Mg}$ ) depending on facility size. In contrast, low stover availability would increase delivered costs of large round bales by $\$ 10.80$ to $\$ 16.40 /$ dry ton ( $\$ 11.90$ to $\$ 18.10 /$ dry $\mathrm{Mg}$ ). The high availability case is for near optimal conditions for stover availability and the low availability case is probably uneconomic. Similar results are obtained for the unprocessed pickup system. For the smallest-sized facility, high stover availability would lower delivered costs by about $\$ 6.40 /$ dry ton $(\$ 7.10 / \mathrm{dry} \mathrm{Mg})$ and by $\$ 12.80 / \mathrm{dry}$ ton $(\$ 14.10 / \mathrm{dry} \mathrm{Mg})$ ) for the largest facility shown. Low stover availability increases costs substantially over the base case. This is due primarily to the use of the high-speed tractors and wagons for hauling stover from the field to storage.

Our results generally indicate that delivered costs of baled stover in large round bales can be reduced to under $\$ 40 /$ dry ton $(\$ 44.10 /$ dry $\mathrm{Mg}$ ) provided high availability conditions can be found. For the unprocessed pickup system, high availability can lower delivered cost to under $\$ 30 /$ dry ton ( $\$ 33.10 /$ dry $\mathrm{Mg}$ ) provided high capacity wagons can be used and compacted bales can be made efficiently. 
Table 3. Summary of delivered stover costs for large round, rectangular bales, and unprocessed/pickup system bales (high and low cost)

\begin{tabular}{|c|c|c|c|c|}
\hline \multirow[t]{2}{*}{ Bale system } & \multicolumn{4}{|c|}{ Facility size } \\
\hline & 500 & 1000 & 2000 & 4000 \\
\hline & \multicolumn{4}{|c|}{$\$ /$ dry ton } \\
\hline \multicolumn{5}{|l|}{ Large round bales } \\
\hline Delivered cost in storage & $\$ 23.68$ & $\$ 23.94$ & $\$ 24.29$ & $\$ 24.80$ \\
\hline Transport cost & $\$ 7.02$ & $\$ 7.71$ & $\$ 8.68$ & $\$ 10.06$ \\
\hline Farmer payments & $\$ 10.00$ & $\$ 10.00$ & $\$ 10.00$ & $\$ 10.00$ \\
\hline Operation expenses $(5 \%)$ & $\$ 2.04$ & $\$ 2.08$ & $\$ 2.15$ & $\$ 2.24$ \\
\hline Total delivered at conversion facility & $\$ 42.74$ & $\$ 43.73$ & $\$ 45.12$ & $\$ 47.10$ \\
\hline \multicolumn{5}{|l|}{ Large rectangular bales } \\
\hline Delivered cost in storage & $\$ 24.07$ & $\$ 24.34$ & $\$ 24.72$ & $\$ 22.25$ \\
\hline Transport cost & $\$ 7.18$ & $\$ 7.96$ & $\$ 9.06$ & $\$ 10.62$ \\
\hline Farmer payments & $\$ 10.00$ & $\$ 10.00$ & $\$ 10.00$ & $\$ 10.00$ \\
\hline Operation expenses $(5 \%)$ & $\$ 2.06$ & $\$ 2.12$ & $\$ 2.19$ & $\$ 2.29$ \\
\hline Total delivered at conversion facility & $\$ 43.32$ & $\$ 44.42$ & $\$ 45.97$ & $\$ 48.17$ \\
\hline \multicolumn{5}{|l|}{ Unprocessed pickup - high cost } \\
\hline Delivered cost in storage & $\$ 19.92$ & $\$ 23.29$ & $\$ 24.99$ & $\$ 26.80$ \\
\hline Transport cost & $\$ 4.23$ & $\$ 4.93$ & $\$ 5.92$ & $\$ 7.32$ \\
\hline Farmer payments & $\$ 10.00$ & $\$ 10.00$ & $\$ 10.00$ & $\$ 10.00$ \\
\hline Operation expenses $(5 \%)$ & $\$ 1.71$ & $\$ 1.91$ & $\$ 2.05$ & $\$ 2.21$ \\
\hline Total delivered at conversion facility & $\$ 35.85$ & $\$ 40.12$ & $\$ 42.95$ & $\$ 46.32$ \\
\hline \multicolumn{5}{|l|}{ Unprocessed pickup - low cost } \\
\hline Delivered cost in storage & $\$ 15.92$ & $\$ 17.76$ & $\$ 19.25$ & $\$ 21.67$ \\
\hline Transport cost & $\$ 4.23$ & $\$ 4.93$ & $\$ 5.92$ & $\$ 7.32$ \\
\hline Farmer payments & $\$ 10.00$ & $\$ 10.00$ & $\$ 10.00$ & $\$ 10.00$ \\
\hline Operation expenses $(5 \%)$ & $\$ 1.51$ & $\$ 1.63$ & $\$ 1.76$ & $\$ 1.95$ \\
\hline Total delivered at conversion facility & $\$ 31.65$ & $\$ 34.32$ & $\$ 36.92$ & $\$ 40.94$ \\
\hline Total delivered at conversion facility & \multicolumn{4}{|c|}{$\$ /$ dry Mg } \\
\hline Large round bales & $\$ 47.12$ & $\$ 48.21$ & $\$ 49.74$ & $\$ 51.93$ \\
\hline Large rectangular bales & $\$ 47.76$ & $\$ 48.97$ & $\$ 50.68$ & $\$ 53.11$ \\
\hline Unprocessed pickup - high cost & $\$ 39.52$ & $\$ 44.23$ & $\$ 47.35$ & $\$ 51.07$ \\
\hline Unprocessed pickup - low cost & $\$ 34.89$ & $\$ 37.84$ & $\$ 46.70$ & $\$ 45.14$ \\
\hline
\end{tabular}

Note: Unprocessed pickup (high cost) represents the $1100 \mathrm{ft}^{3}\left(31.2 \mathrm{~m}^{3}\right)$ size wagon without compressing capability. Low cost represents the $2200 \mathrm{ft}^{3}\left(62.3 \mathrm{~m}^{3}\right)$ size wagon with compressing capability. 


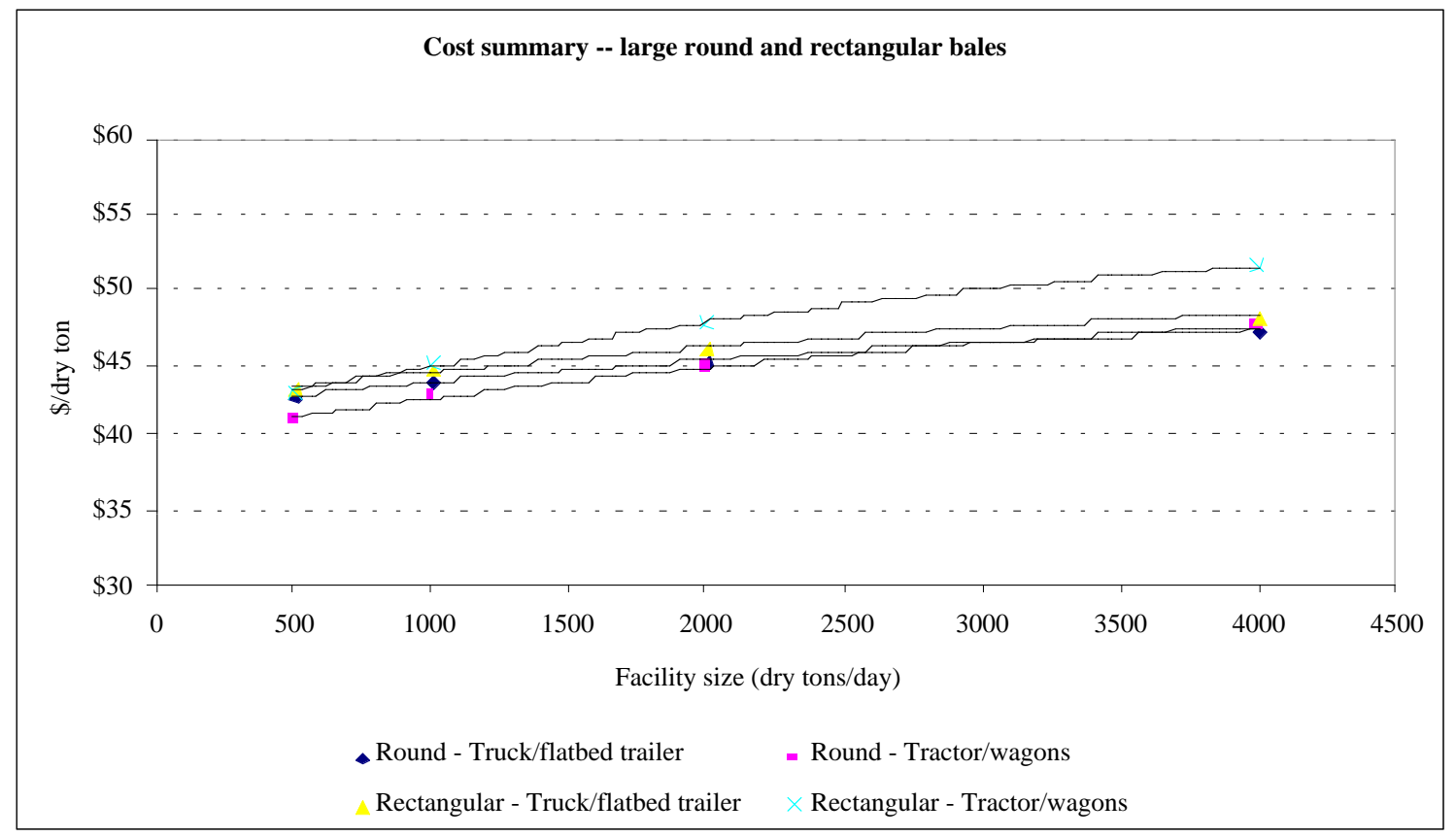

Fig. 8. Cost summary for conventional bale systems.

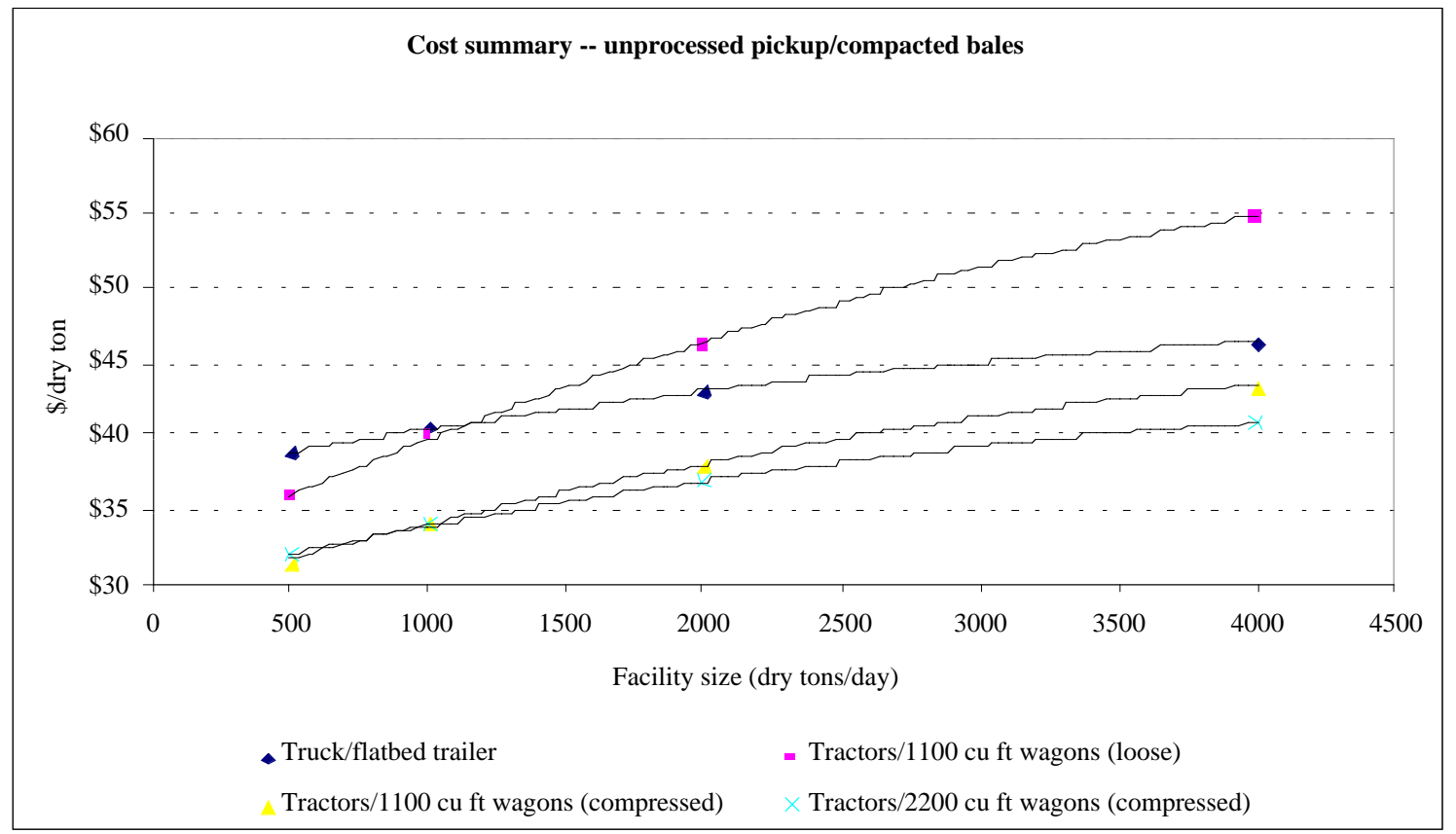

Fig. 9. Cost summary for unprocessed pickup/compacted bale systems. 


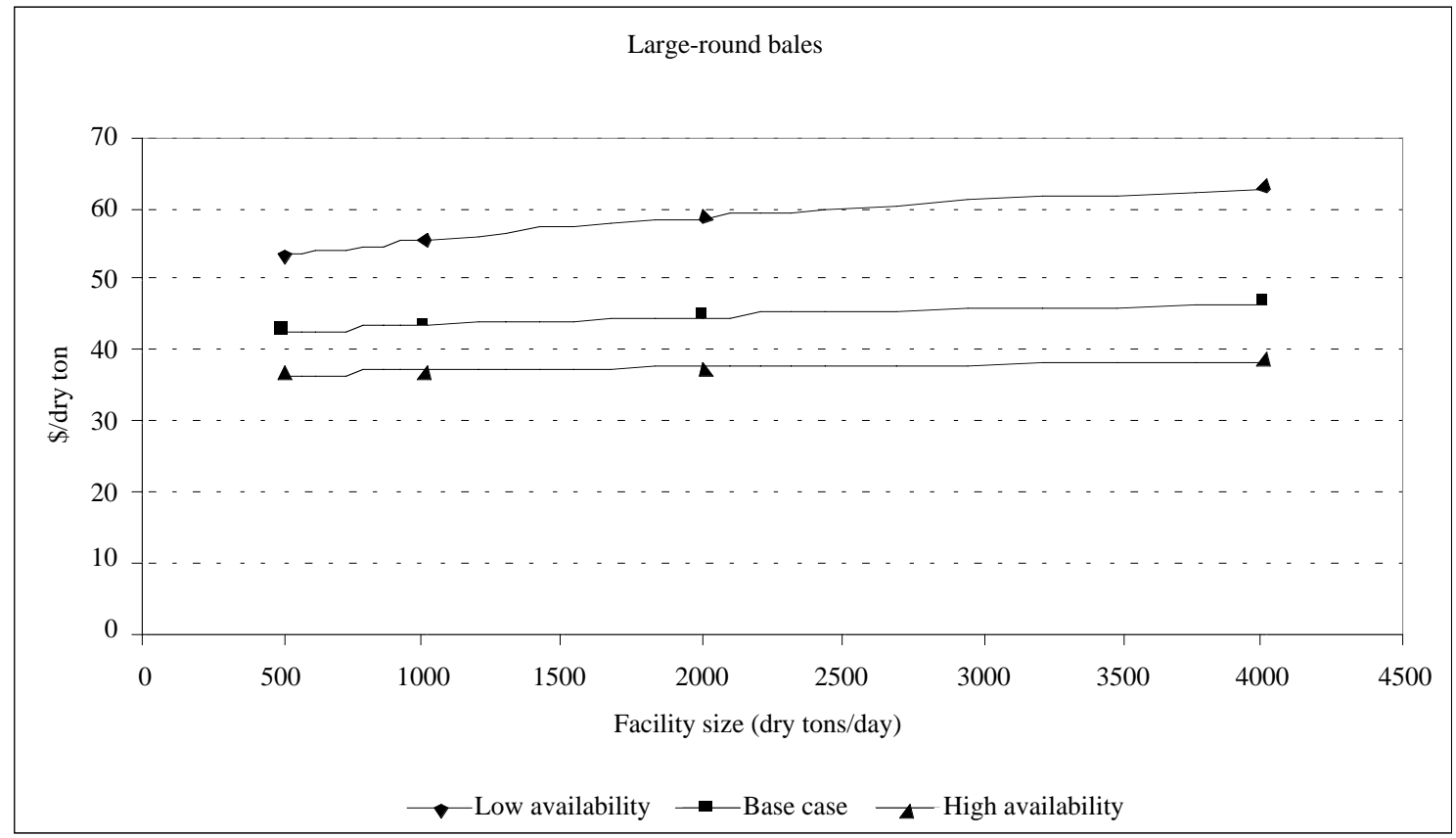

Fig. 10. Sensitivity of delivered costs to changes in stover availability - large round bales.

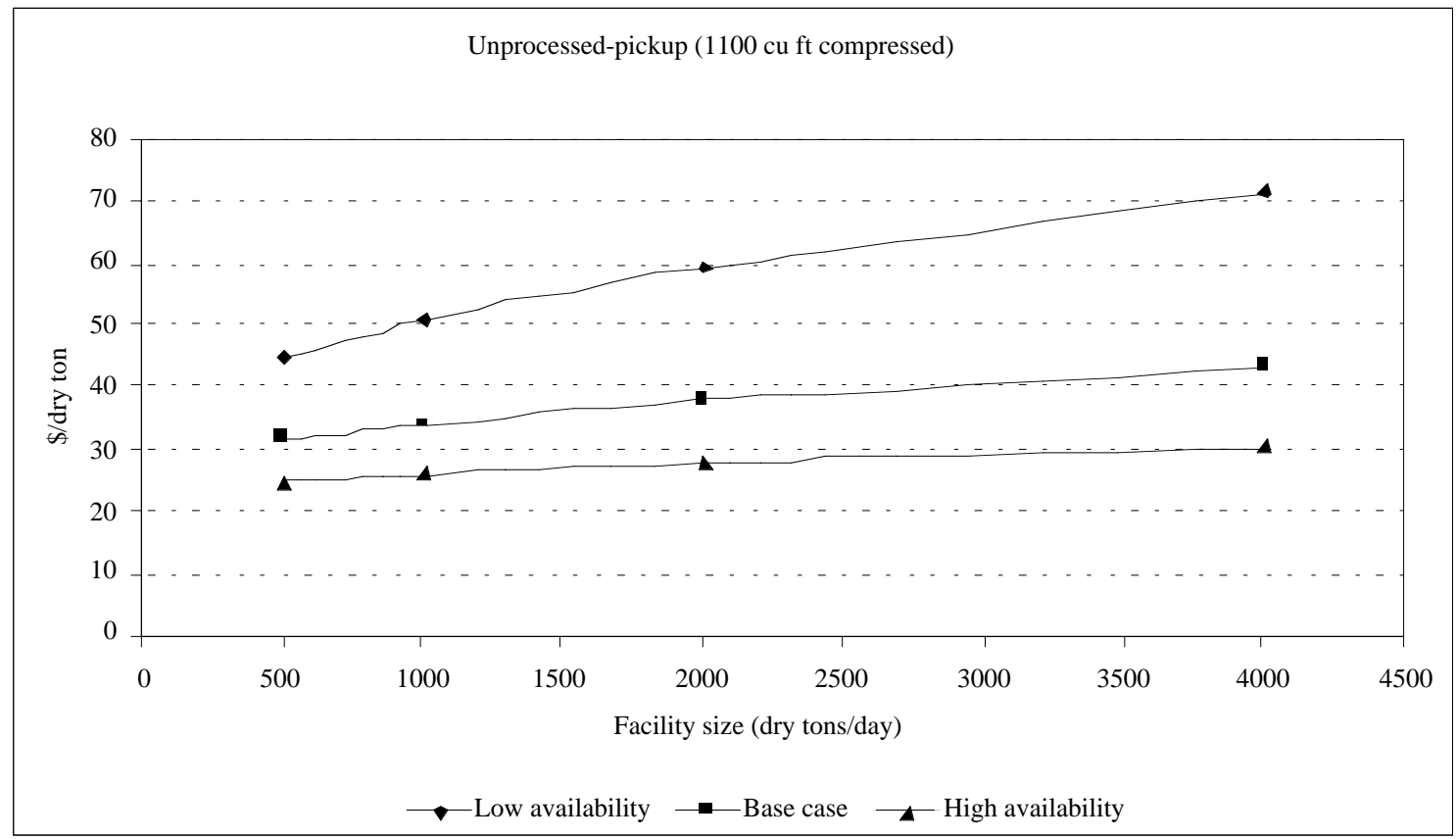

Fig. 11. Sensitivity of delivered costs to changes in stover availability - unprocessed pickup system. 


\section{CONCLUSIONS}

We evaluated the logistics and estimated the delivered costs for collecting, handling, and hauling corn stover to an ethanol conversion facility using two conventional baling systems, a silage collection system, and a unprocessed pickup system. Delivered costs for the large round bales and large rectangular bale systems are in the range of about $\$ 42.70$ to $\$ 47.10 /$ dry ton $(\$ 47.10-\$ 51.90 /$ dry $\mathrm{Mg}$ ) for conversion facilities of 500 to 4000 dry tons/day (450 - 1810 dry $\mathrm{Mg} /$ day. We find moving large round bales directly from the field to storage is less costly than staging the bales at the field edge and moving them to storage on trucks/flatbed trailers. For the large rectangular bales, field staging and truck haul to storage is less costly for all but the smallest sized facilities. We also find that truck haul from storage is much less expensive than hauling bales on wagons to a conversion facility. We modeled two non-conventional systems. The least expensive one (unprocessed pickup) had delivered costs lower than the conventional systems. When we increased the packing density of the wagons and volume we found costs could be significantly reduced, perhaps to $\$ 35 /$ dry ton

(\$38.60/dry Mg) for facilities under 1000 dry tons/day (910 dry $\mathrm{Mg} / \mathrm{day})$. Our results suggest that additional research in wagon design and compaction may be warranted for the unprocessed-pickup system. 


\section{REFERENCES}

ASAE, ASAE Standards 1998, 45th ed., American Society of Agricultural Engineers, St. Joseph, MI, 1998.

Glasner, D. A., J. R. Hettenhaus, and T. M. Schechinger, Corn Stover Collection Project, BioEnergy '98: Expanding BioEnergy Partnerships, Madison WI, 1998.

Glasner, D. A., J. R. Hettenhaus, and T. M. Schechinger, Corn Stover Potential: recasting the Corn Sweetener Industry, in J. Janick (ed.), Perspectives on New crops and New Uses, pp. 74-82, ASHS Press, Alexandria VA, 1999.

Heartland Ag-Business Group, Hot Line Farm Equipment Guide, quick reference guide, 18th ed., Heartland Ag-Business Group, Fort Dodge, IA, 1999.

Hettenhaus, J. R., R. Wooley, and A. Wiselogel, Biomass Commercialization Prospects in the Next 2 to 5 Years: Biomass Colloquies 2000, National Renewable Energy Laboratory, NREL/ACO-9-29-039-1, October 2000.

Nielsen, R. A., Questions Relative to Harvesting and Storing Corn Stover, Agronomy Extension Publication AGRY-95-09, Purdue University, West Lafayette, 1995.

Sayler R., K. von Bargen, M. Meagher, W. Scheller, and M. Turner, Feasibility of Corn Residue Collection in Kearney, Nebraska Area, Report prepared for the Western Regional Biomass Program, Golden CO, September 1993.

Schechinger T. M. and J. Hettenhaus, Corn Stover Harvest: Grower, Custom Operator, and Processor Issues and Answers, Iron Horse Custom Farms, Harlan IA, September 1999.

Sperling, D., AAn Analytical Framework for Siting and Sizing Biomass Fuel Plants, @ Energy, 9 (1112):1033-1040, 1984.

Turhollow, A., R. D. Perlack, and B. Wilson, A Financial-Engineering Cost Model for Analyzing the Collection, Handling, Transport, and Processing of Agricultural Residues, Oak Ridge National Laboratory, Oak Ridge, TN, forthcoming 2001.

USDA/NASS, Agricultural Prices, U.S. Department of Agriculture, National Agricultural Statistics Service, Washington, 1999.

Walsh, M. E., B. C. English, J. Menard, C. Brandt, R. Wooley, A. Turhollow, and D. de la Torre Ugarte, Economic Impacts of a Corn Stover to Ethanol Industry, Proceedings of the Renewable Energy from Organics Recycling Conference, Ames, Iowa, Oct. 29-Oct. 31, 2001. 
APPENDIX A

DETAILED EQUIPMENT COSTS 
Table A.1. Financial assumptions

\begin{tabular}{|l|c|}
\hline Assumption & Value \\
\hline Interest rate & $6.5 \%$ \\
Farm labor wage rate (\$/hour) & $\$ 8.50$ \\
Farm labor benefits rate & 0.1 \\
Truck labor wage rate & $\$ 14.40$ \\
Truck labor benefits rate & 0.2 \\
Fuel (\$/gallon) & $\$ 1.10$ \\
Fuel tax (\$/gallon) & $\$ 0.35$ \\
Oil (\$/gallon) & $\$ 5.30$ \\
Purchase price/list price ratio & 0.9 \\
Labor hours/machine hours ratio & 1.2 \\
\hline
\end{tabular}

